\title{
The role of angiogenic factors in predicting clinical outcome in severe bacterial infection in Malawian children
}

\author{
Limangeni A Mankhambo 1,2, Daniel L Banda1, The IPD Study Group1', Graham Jeffers4', Sarah A White1, Paul Balmer³, \\ Standwell Nkhoma' ${ }^{1}$, Happy Phiri', Elizabeth M Molyneux², C Anthony Hart5, Malcolm E Molyneux', \\ Robert S Heyderman ${ }^{1}$ and Enitan D Carro* ${ }^{* 1,4}$
}

\begin{abstract}
Introduction: Severe sepsis is a disease of the microcirculation, with endothelial dysfunction playing a key role in its pathogenesis and subsequent associated mortality. Angiogenesis in damaged small vessels may ameliorate this dysfunction. The aim of the study was to determine whether the angiogenic factors (vascular endothelial growth factor (VEGF), platelet-derived growth factor (PDGF), fibroblast growth factor (FGF), and angiopoietin-1 (Ang-1) and -2 (Ang2)) are mortality indicators in Malawian children with severe bacterial infection.
\end{abstract}

Methods: In 293 children with severe bacterial infection, plasma VEGF, PDGF, FGF, and Ang-1 and Ang-2 were measured on admission; in 50 of the children with meningitis, VEGF, PDGF, and FGF were also measured in the CSF. Healthy controls comprised children from some of the villages of the index cases. Univariable and multivariable logistic regression analyses were performed to develop a prognostic model.

Results: The median age was 2.4 years, and the IQR, 0.7 to 6.0 years. There were 211 children with bacterial meningitis (72\%) and 82 (28\%) with pneumonia, and 154 (53\%) children were HIV infected. Mean VEGF, PDGF, and FGF concentrations were higher in survivors than in nonsurvivors, but only PDGF remained significantly increased in multivariate analysis $(P=0.007)$. Mean Ang-1 was significantly increased, and Ang-2 was significantly decreased in survivors compared with nonsurvivors $(6,000$ versus $3,900 \mathrm{pg} / \mathrm{ml}, P=0.03$; and 7,700 versus $11,900 \mathrm{pg} / \mathrm{ml}, P=0.02$, respectively). With a logistic regression model and controlling for confounding factors, only female sex (OR, 3.95; $95 \%$ $\mathrm{Cl}, 1.33$ to 11.76$)$ and low Ang-1 (OR, $0.23 ; 95 \% \mathrm{Cl}, 0.08$ to 0.69$)$ were significantly associated with mortality. In children with bacterial meningitis, mean CSF VEGF, PDGF, and FGF concentrations were higher than paired plasma concentrations, and mean CSF, VEGF, and FGF concentrations were higher in nonsurvivors than in survivors $(P=0.02$ and 0.001 , respectively).

Conclusions: Lower plasma VEGF, PDGF, FGF, and Ang-1 concentrations and higher Ang-2 concentrations are associated with an unfavorable outcome in children with severe bacterial infection. These angiogenic factors may be important in the endothelial dysregulation seen in severe bacterial infection, and they could be used as biomarkers for the early identification of patients at risk of a poor outcome.

\section{Introduction}

Sepsis remains a leading cause of death in children in the developing world, accounting for some $60 \%$ of childhood

\footnotetext{
* Correspondence: edcarrol@liv.ac.uk

1 Malawi-Liverpool-Wellcome Trust Clinical Research Programme, College of

Medicine, University of Malawi, Blantyre, Malawi

$\wedge$ Deceased

Full list of author information is available at the end of the article
}

mortality. Streptococcus pneumoniae and Haemophilus influenzae type b, two pathogens responsible for most childhood deaths of pneumonia and bacterial meningitis, caused more than a million deaths globally in children younger than 5 years in 2000 [1,2]. Severe sepsis is a disease of the microcirculation, with endothelial dysfunction playing a key role in its pathogenesis and subsequent associated mortality [3]. Endothelial progenitor cells 
from the bone marrow ameliorate the dysfunction caused by severe sepsis, and this process is thought to be mediated by angiogenesis in ischemic areas and in damaged small vessels $[4,5]$.

Growth factors are recognized for their ability to induce cellular proliferation and differentiation. Vascular endothelial growth factor (VEGF), a dimeric 46-kDa glycoprotein, is an endothelial cell-specific, multifunctional cytokine. VEGF is a potent regulator of vascular permeability and angiogenesis, and in endothelial cells, induces the expression of cell-adhesion molecules and the release of cytokines and chemokines [6,7]. Platelet-derived growth factor (PDGF) has angiogenic effects and stimulates endothelial cell migration [8,9]. Despite the name "platelet derived," studies suggest that the endothelium rather than platelets might be a major source of PDGF in sepsis [10]. Fibroblast growth factor (FGF) promotes angiogenesis and also has antiapoptotic effects $[11,12]$. Elevated CSF levels of FGF have been observed in children with bacterial meningitis and are associated with poor outcome, suggesting neurotropic effects [13].

The angiopoietins, angiopoietin-1 (Ang-1) and angiopoietin-2 (Ang-2), play a fundamental role in the maintenance of vessel integrity. Angiopoietin-1 (Ang-1) and Ang-2 are ligands of the endothelial receptor tyrosine kinase Tie-2, which is a key regulator of endothelial function [14]. Binding of circulating Ang-1 to the Tie-2 receptor protects the vasculature from inflammation and leakage, whereas binding of Ang-2 antagonizes Tie-2 signaling and disrupts endothelial barrier function. Ang-1 is important for blood vessel stability, inhibiting vascular leakage, and suppressing inflammatory gene expression $[15,16]$. Ang- 2 is generally an antagonist of Ang-1, but in the presence of VEGF, promotes cell survival [17]. Both Ang-1 and VEGF concentrations have been reported to be significantly lower in patients with sepsis than in controls, but Ang-2 levels are higher and are associated with disease severity $[18,19]$. PDGF stimulation of vascular smooth muscle cells leads to a decrease in Ang-2 levels [20]. Elevated Ang-2 levels have been reported in severe sepsis and septic shock and may contribute to sepsisrelated capillary leak [19,21-23].

Clinical data from adult studies [24-28] support the association of elevated plasma growth factor concentrations with sepsis. Studies in children have demonstrated increased plasma VEGF concentrations in meningococcal sepsis [29] and community-acquired pneumonia [30], and increased plasma PDGF and VEGF in respiratory syncytial virus infection [31], but these three growth factors together with Ang-1 and Ang-2 have never previously been explored in a large study in children. Given that the angiogenic factors have been identified as predictors of disease severity in sepsis, we aimed to determine whether the five angiogenic factors (PDGF, VEGF, FGF, and Ang-1 and Ang-2) may be mortality indicators in a population with a high burden of parasitic and HIV infection. We also aimed to investigate whether evidence exists of a relation between intracerebral production of angiogenic factors and mortality in bacterial meningitis. We selected three growth factors and two angiopoietins in an attempt to understand whether they may play a role in the mobilization of endothelial progenitor cells in severe bacterial infection.

\section{Materials and methods}

\section{Ethics statement}

Ethical approval for this study was granted from The College of Medicine Research Committee (COMREC), Malawi, and The Liverpool School of Tropical Medicine Local Research Ethics Committee. Parents or guardians gave written informed consent for children to enter the study.

\section{Study population}

The study was part of a larger prospective observational study investigating the genetic susceptibility to invasive pneumococcal disease in Malawian children [32]. This study was conducted at Queen Elizabeth Central Hospital $(\mathrm{QECH})$ in Blantyre, Malawi, between April 2004 and October 2006. We recruited children aged between 2 months and 16 years with a suspected diagnosis of bacterial meningitis or pneumonia. Details on enrolment criteria, laboratory methods, and management protocols were described elsewhere [33]. We also collected data on the duration of symptoms and on previous antibiotic administration. As our previous data indicated that these factors did not influence outcome in multivariate analysis, we did not include them in the analysis reported here [33]. We recorded the Blantyre Coma Score (BCS) on admission [34]; this has a scale from 0 to 5 , with a score of $\leq 2$ defining coma. We assessed each child's nutritional status by using weight-for-height $\mathrm{Z}$ scores and height-forage $\mathrm{Z}$ scores. In total, we recruited 377 children to the parent study, but angiogenic factor determination was performed on only the first 293 cases, who constituted the study population of the present investigation. Pneumococcal bacterial loads were determined as previously described [33].

We used the following definitions:

Cases $(n=293)$ : Children first seen with signs and symptoms of bacterial meningitis or pneumonia in whom growth factors were determined.

Healthy controls $(n=15)$ : Healthy afebrile children from the same villages as the cases, who had no malarial parasites on blood film. Controls were selected by parents or guardians in the neighborhood of the index case as part of a larger study investigating genetic susceptibility in IPD [32]. In a small number of children, parental con- 
sent also was given to take venous samples for cytokine and angiogenic factor determination.

Invasive pneumococcal disease (IPD) $(n=180)$ : S. pneumoniae was identified (by culture, microscopy, and Gram stain, antigen testing, or PCR) from one or more of the following normally sterile body sites: blood, cerebrospinal fluid, lung aspirate.

Serious bacterial infection (SBI) $(n=216)$ : Children with bacterial meningitis or pneumonia, and in whom a bacterial pathogen was identified by culture, polysaccharide antigen test, or PCR in blood, cerebrospinal fluid or lung aspirate fluid (Streptococcus pneumoniae, Neisseria meningitidis, and Haemophilus influenzae $b$ ).

No detectable bacterial infection (NBI) $(n=77)$ : Children with bacterial meningitis or pneumonia, but who were negative for any bacteria on culture, polysaccharide antigen test, or PCR (S. pneumoniae, N. meningitidis, and H. influenzae $b$ ).

Pneumonia $(n=82)$ : Confirmed by radiology and positive blood or lung aspirate by culture or PCR.

Bacterial meningitis $(n=211)$ : Confirmed by CSF cell count (>10 per microliter) and one of the following tests: CSF culture, Gram stain, polysaccharide antigen, or PCR positive.

\section{Growth factor, Ang-1, and Ang-2 determination}

Growth-factor determination was performed in plasma and CSF samples by using Luminex 100 technology in the Bio-plex Protein Array System (Bio-Rad Laboratories. Inc., Santa Clara, California, USA) by using a 27-plex Bioplex Human Cytokine kit, which includes IL-1 $\beta$, IL-1ra, IL-2, IL-4, IL-5, IL-6, IL-7, IL-8, IL-9, IL-10, IL-12 (p70), IL-13, IL-15, IL-17, eotaxin, basic FGF, G-CSF, GM-CSF, IFN- $\gamma$, IP-10, MCP-1 (MCAF), MIP- $1 \alpha$, MIP-1 $\beta$, PDGFBB, RANTES, TNF- $\alpha$, and VEGF (Bio-Rad Laboratories), according to the manufacturer's instructions. In 50 children with bacterial meningitis, in whom sufficient CSF existed for analysis, CSF growth factors were determined on admission. Plasma Ang-1 and Ang-2 were determined by using a commercial ELISA assay (R\&D Systems Europe, Ltd., Abingdon, UK). We have previously reported the analysis of chemokines and pro-and antiinflammatory cytokines in this cohort $[33,35]$.

\section{HIV determination}

HIV status was assessed in children 18 months or older by using at least two of the following tests; Unigold and Serocard (Trinity Biotech, Wicklow, Ireland), or Determine-HIV (Abbott Laboratories, Springfield, IL, USA). At least two tests were required to be positive for a subject to be classified as HIV infected. In children younger than 18 months, and in those with discordant antibody tests, HIV status was determined by using Amplicor HIV-
1 DNA Test version 1.5 (Roche Diagnostics, South San Francisco, CA, USA).

\section{Statistical analysis}

The growth factors and angiopoietins determined were summarized by using geometric means and interquartile ranges (IQRs). Two-sample $t$ tests were used to compare growth-factor concentrations between groups, by using $\log$-transformed data. Multiway analyses of variance were used to obtain adjusted comparisons for each factor of interest (main effects: SBI/NBI, pneumonia/meningitis, HIV status, survivor/nonsurvivor, and gram positive/negative infection). Correlations between growth factors and other variables were estimated by using Spearman's rho correlation coefficient. Fisher's Exact test was used to compare proportions. Univariable and multivariable logistic regression analyses were performed to develop a prognostic model of the influence of confounding factors (HIV status, age, sex, diagnosis, and previous antibiotics) on the primary outcome measure, inpatient mortality. CSF and plasma growth factors in children with bacterial meningitis were analyzed by using Wilcoxon's Signed Ranks test. Adjusted odds ratios (ORs) were obtained by using logistic regression. All tests were two-tailed, and a $P$ value of $<0.05$ was considered significant.

\section{Results}

\section{Patient characteristics}

We studied 293 children (57\% boys), of whom 64 (22\%) died. The median age was 2.4 years, and the IQR, 0.7 to 6.0 years. The 211 (72\%) children were first seen with bacterial meningitis, and 82 (28\%), with pneumonia; 154 (53\%) children were HIV infected (50\% of those with meningitis, and $60 \%$ of those with pneumonia). Baseline characteristics of study patients are shown in Table 1. In total, 216 (74\%) children had a serious bacterial infection (SBI), and 77 had no organism identified (NBI). Of the 216 children with SBI, 182 (62\%) had a gram-positive organism, $33(11 \%)$ had a gram-negative organism, and one child had both gram-positive and -negative infections. The etiologies of both pneumonia and meningitis are shown in Table 2.

\section{Plasma VEGF, PDGF, and FGF in children with severe bacterial infection}

Plasma VEGF, PDGF, and FGF on admission were significantly elevated in children with severe bacterial infection compared with healthy controls (Table 3). No significant difference in plasma growth factors was found between children with bacterial meningitis and those with pneumonia or between HIV-infected and HIV-uninfected children. The mean plasma VEGF concentrations were significantly higher in children with SBI compared with those with NBI, and plasma concentrations of all three 
Table 1: Demographic, clinical, and laboratory characteristics of study patients by disease presentation

\begin{tabular}{|c|c|c|c|}
\hline & Meningitis & Pneumonia & $P$ value \\
\hline No. of patients & 211 & 82 & \\
\hline Age in years (median, IQR) & $2.3(0.6-6.0)$ & $2.7(0.9-5.6)$ & NS \\
\hline Gender (male) (\%) & $116(55 \%)$ & $52(63 \%)$ & NS \\
\hline $\mathrm{SBI}(\%)$ & $176(83 \%)$ & $40(49 \%)$ & 0.0005 \\
\hline Gram-positive infection (\%)a & $146(69 \%)$ & $36(44 \%)$ & NS \\
\hline Gram-negative infection (\%) ${ }^{\mathrm{a}}$ & $29(14 \%)$ & $4(5 \%)$ & NS \\
\hline Blantyre Coma Score $\leq 2$ (\%) & $88(42 \%)$ & $1(1 \%)$ & 0.0005 \\
\hline HIV infected (\%) & $105(50 \%)$ & $49(60 \%)$ & NS \\
\hline Duration of symptoms in days (median, IQR) & $3(2-4)$ & $3(3-6)$ & 0.001 \\
\hline Inpatient mortality (\%) & $58(28 \%)$ & $6(7 \%)$ & 0.0005 \\
\hline Wasting (weight-for-height Z score $\leq 3 \mathrm{SD}$ ) & $33 / 172(19 \%)$ & $7 / 69(10 \%)$ & NS \\
\hline Stunting (height-for-age $Z$ score $\leq 3 \mathrm{SD}$ ) & $31 / 206(15 \%)$ & $16 / 79(20 \%)$ & NS \\
\hline White cell count $\left(\times 10^{9} / L\right)$ (median, IQR) & $11.8(7.3-19.2)$ & $15.7(9.9-25.3)$ & 0.001 \\
\hline C-reactive protein (mg/L) (median, IQR) & $258(162-323)$ & $275(56-345)$ & NS \\
\hline Glucose (mmol/L) (median, IQR) & $6.1(4.8-7.6)$ & $5.2(4.4-6.0)$ & 0.0005 \\
\hline Lactate (mmol/L) (median, IQR) & $3.9(2.4-6.3)$ & $2.6(1.8-5.2)$ & 0.006 \\
\hline Systolic BP(mm Hg) (median, IQR) & $103(93-115)$ & $100(89-110)$ & NS \\
\hline Diastolic BP(mm Hg) (median, IQR) & $66(59-80)$ & $66(59-76)$ & NS \\
\hline
\end{tabular}

growth factors were significantly higher in patients with gram-positive than in those with gram-negative infections (Table 3). Mean plasma PDGF concentrations were significantly higher in survivors compared with nonsurvivors. VEGF, PDGF, and FGF concentrations were significantly higher in children with invasive pneumococcal disease compared with children with SBI caused by pathogens other than S. pneumoniae (Table 3). PDGF concentrations were lower in children who had received antibiotics before hospital admission $(P=0.02)$. No significant differences were noted in mean VEGF, PDGF, and FGF concentrations in children with wasting or stunting and those without, and no correlation occurred with duration of symptoms (data not shown). 
Table 2: Etiology of pneumonia and meningitis

\begin{tabular}{lcc}
\hline Organism & Meningitis & Pneumonia \\
\hline Streptococcus pneumoniae & 144 & 36 \\
\hline Neisseria meningitidis & 10 & 1 \\
\hline Salmonella enterica serovar Typhimurium & 5 & 0 \\
\hline Salmonella enterica serovar Enteritidis & 2 & 3 \\
\hline Haemophilus influenzae $b$ & 7 & 0 \\
\hline Haemophilus influenzae & 3 & 0 \\
\hline Mixed S. enterica/S. pneumoniae & 1 & 82 \\
\hline Other (E. coli, K. pneumoniae, S. pyogenes, S. aureus) & & 0 \\
\hline Negative & 4 & 42 \\
\hline Total & 35 & 0 \\
\hline
\end{tabular}

\section{CSF VEGF, PDGF, and FGF in children with bacterial meningitis}

In 50 children with bacterial meningitis, CSF VEGF, PDGF, and FGF were measured. CSF concentrations of VEGF, PDGF, and FGF were significantly higher than paired plasma concentrations $(P=0.001 ; P<0.005$; and $P$ $<0.0005$, respectively, Wilcoxon signed rank test). No significant correlations appeared between the CSF concentrations of VEGF, PDGF, or FGF and the CSF white cell count, CSF absolute neutrophil count, or Blantyre coma score. In children with pneumococcal meningitis $(n=30)$, significant correlations were noted between CSF pneumococcal bacterial load and the concentration of VEGF and FGF in the CSF (Figure 1), and the CSF concentrations of both of these growth factors were higher in patients who died than in those who survived.

No significant differences were found in CSF VEGF, PDGF, and FGF levels between children with coma (BCS $\leq 2)$ and those without. In contrast to plasma concentrations, mean CSF, VEGF, and FGF concentrations were higher in nonsurvivors than in survivors $(1,178$ versus $216 \mathrm{pg} / \mathrm{ml} ; P=0.02$; and 939 versus $501 \mathrm{pg} / \mathrm{ml} ; P=0.001$, respectively).

\section{Plasma Ang-1 and Ang-2 in children with severe bacterial sepsis}

Plasma Ang-2 on admission was significantly increased in children with severe bacterial infection compared with healthy controls, but Ang-1 was not significantly different (Table 3). No significant differences in Ang-1 and Ang-2 concentrations were noted between children with meningitis and those with pneumonia, but Ang-2 was significantly elevated in HIV-infected children. The mean plasma Ang-1 concentrations were significantly lower in children with SBI compared with those with NBI, but Ang-2 was significantly higher after adjustment for confounding variables. Ang-1 and Ang-2 plasma concentrations were not significantly different between grampositive and gram-negative infections (Table 3). Mean plasma Ang-1 concentrations were significantly higher, and Ang-2, significantly lower in survivors compared with nonsurvivors (Table 3). The ratio of lnAng-2 (natural log Ang-2) to lnAng-1 was higher in nonsurvivors compared with survivors $(P=0.03)$. Plasma Ang-1 concentrations were not significantly different in children with invasive pneumococcal disease compared with children with SBI caused by pathogens other than S. pneumoniae (Table 3). Plasma Ang-2 correlated positively with the pro- and antiinflammatory cytokines, IL-1Ra, IL-6, IL-8, and IL-10 (Table 4).

Logistic regression models for predicting mortality and SBI The plasma values of VEGF, PDGF, FGF, Ang-1, and Ang2 were $\log$ transformed and included in a multivariate stepwise logistic regression model, including HIV status, sex, diagnosis (pneumonia or meningitis), and admission 
Table 3: Summary of growth factors in Malawian children with sepsis

\begin{tabular}{|c|c|c|c|c|c|}
\hline $\begin{array}{l}\text { Geometric mean }(25 \%-75 \% \\
\text { centile) } \\
P \text { values: univariable } \\
\text { (multivariablea) }\end{array}$ & VEGF pg/ml & PDGF pg/ml & FGF pg/ml & Ang $11,000 \mathrm{pg} / \mathrm{ml}$ & Ang2 1,000 pg/ml \\
\hline Cases $(n=293)$ & $90(53-166)$ & $956(548-1884)$ & $204(119-376)$ & $5.54(2.6-9.7)$ & $8.5(5.2-13.6)$ \\
\hline Controls $(n=15)$ & $\begin{array}{l}11(4,15) \\
P<0.001\end{array}$ & $\begin{array}{c}402(195-721) \\
P=0.04\end{array}$ & $\begin{array}{l}34(20-48) \\
P<0.001\end{array}$ & $\begin{array}{c}6.84(2.2-20.1) \\
P=0.58\end{array}$ & $\begin{array}{c}2.4(1.6-4.6) \\
P<0.001\end{array}$ \\
\hline $\mathrm{NBI}(n=77)$ & $77(49-133)$ & $1,069.4(702-2,309)$ & $210(141-342)$ & $8.4(3.9-16.8)$ & $5.3(3.1-7.6)$ \\
\hline $\mathrm{SBI}(n=216)$ & $\begin{array}{c}96(56-171) \\
P=0.06(0.02)\end{array}$ & $\begin{array}{c}918(521-1,779) \\
P=0.27(0.71)\end{array}$ & $\begin{array}{c}202(107-89) \\
P=0.75(0.74)\end{array}$ & $\begin{array}{c}4.7(2.4-8.7) \\
P<0.001(0.01)\end{array}$ & $\begin{array}{c}10.0(5.8-16.1) \\
P<0.001(0.002)\end{array}$ \\
\hline Gram-positive infection $(n=182)$ & $102(59-181)$ & $978(574-1,817)$ & $215(118-404)$ & $4.8(2.5-8.9)$ & $10.4(6.1-16.8)$ \\
\hline Gram-negative infection $(n=33)$ & $\begin{array}{c}63(40-96) \\
P=0.004(0.01)\end{array}$ & $\begin{array}{c}643(286-1,616) \\
P=0.03(0.03)\end{array}$ & $\begin{array}{c}134(84-278) \\
P=0.007(0.004)\end{array}$ & $\begin{array}{c}4.2(1.8-8.6) \\
P=0.41(0.54)\end{array}$ & $\begin{array}{c}9.1(5.7-14.2) \\
P=0.23(0.61)\end{array}$ \\
\hline Pneumonia $(n=211)$ & $88(54-155)$ & $900(528-1,756)$ & $193(116-356)$ & $5.1(2.5-9.6)$ & $9.0(5.3-15.8)$ \\
\hline Meningitis $(n=82)$ & $\begin{array}{c}97(51-200) \\
P=0.38(0.19)\end{array}$ & $\begin{array}{c}1114(676-2,378) \\
P=0.11(0.49)\end{array}$ & $\begin{array}{l}239(131-404) \\
P=0.06(0.15)\end{array}$ & $\begin{array}{c}6.9(3.7-14.6) \\
P=0.10(0.63)\end{array}$ & $\begin{array}{c}7.0(5.2-8.7) \\
P=0.01(0.52)\end{array}$ \\
\hline HIV negative $(n=138)$ & $84(53-145)$ & $937(547-1,720)$ & $201(117-377)$ & $5.4(2.7-9.7)$ & $6.4(3.9-9.2)$ \\
\hline HIV positive $(n=154)$ & $\begin{array}{c}96(53-177) \\
P=0.17(0.45)\end{array}$ & $\begin{array}{c}967(569-2,035) \\
P=0.79(0.95)\end{array}$ & $\begin{array}{l}208(123-375) \\
P=0.71(0.70)\end{array}$ & $\begin{array}{l}5.7(2.5-10.0) \\
P=0.91(0.72)\end{array}$ & $\begin{array}{c}10.9(6.2-16.8) \\
P<0.001(<0.001)\end{array}$ \\
\hline Survivors $(n=229)$ & $93(42-142)$ & $1,051(361-1,261)$ & $214(115-314)$ & $6.0(2.8-10.2)$ & $7.7(5.0-12.6)$ \\
\hline Nonsurvivors $(n=64)$ & $\begin{array}{c}81(54-176) \\
P=0.27(0.19)\end{array}$ & $\begin{array}{l}682(612-2,035) \\
P=0.003(0.007)\end{array}$ & $\begin{array}{l}171(119-385) \\
P=0.07(0.10)\end{array}$ & $\begin{array}{c}3.9(2.3-7.4) \\
P=0.03(0.03)\end{array}$ & $\begin{array}{c}11.9(6.7-21.7) \\
P=0.001(0.02)\end{array}$ \\
\hline $\begin{array}{l}\text { Invasive pneumococcal disease } \\
\text { (IPD) }(n=180)\end{array}$ & $101(58-181)$ & $978(593-1,818)$ & $215(119-397)$ & $4.8(2.5-8.7)$ & $10.4(6.1-16.8)$ \\
\hline SBI, other than IPD $(n=35)$ & $\begin{array}{c}68(41-115) \\
P=0.01\end{array}$ & $\begin{array}{c}671(292-1,611) \\
P=0.04\end{array}$ & $\begin{array}{c}146(86-308) \\
P=0.02\end{array}$ & $\begin{array}{c}4.6(2.0-9.1) \\
P=0.32\end{array}$ & $\begin{array}{l}8.3(5.6-13.0) \\
\quad P=0.16\end{array}$ \\
\hline
\end{tabular}

aMultivariable analyses included NBI/SBI, diagnosis(pneumonia/meningitis), HIV status, survival status and gram-positive/-negative type. (IPD/ SBI, other than IPD was not included in the model because of strong association with gram-positive/negative status. All except two of grampositive infections were IPD).

lactate, as variables in the equation. Female sex (OR, 3.95; 95\% CI, 1.33 to 11.76 ), and Ang-1 (OR, 0.23; 95\% CI, 0.08 to 0.69 ) were significantly associated with mortality. By using a similar model, meningitis (OR, 5.91; 95\% CI, 1.47 to 23.77), admission lactate (OR, 3.20; $95 \% \mathrm{CI}, 1.20$ to 8.57), VEGF (OR, 5.63; 95\% CI, 1.32 to 24.11), Ang-1 (OR, 0.19; 95\% CI, 0.06 to 0.62), and Ang-2 (OR, 5.40; 95\% CI, 1.79 to 16.30$)$ were significantly associated with SBI (Table 5).

\section{Discussion}

Our study examined both growth factors and angiogenic factors in 293 children and demonstrates that among Malawian children with severe bacterial infection, high plasma VEGF, PDGF, FGF, and Ang-1 concentrations are associated with a favorable outcome. In contrast, high Ang-2 concentrations are associated with an unfavorable outcome. In children with bacterial meningitis, our data suggest intracerebral production of angiogenic factors, and an association between high intrathecal concentrations and mortality. Inpatient mortality is high in children admitted with pneumonia and bacterial meningitis in Malawi; therefore, it is important to determine the utility of these angiogenic factors as biomarkers for the identification of patients at risk of a poor outcome.

Our data are in keeping with current evidence that suggests that the growth factors together with Ang-1 may be involved in limiting the deleterious effects of sepsis- 

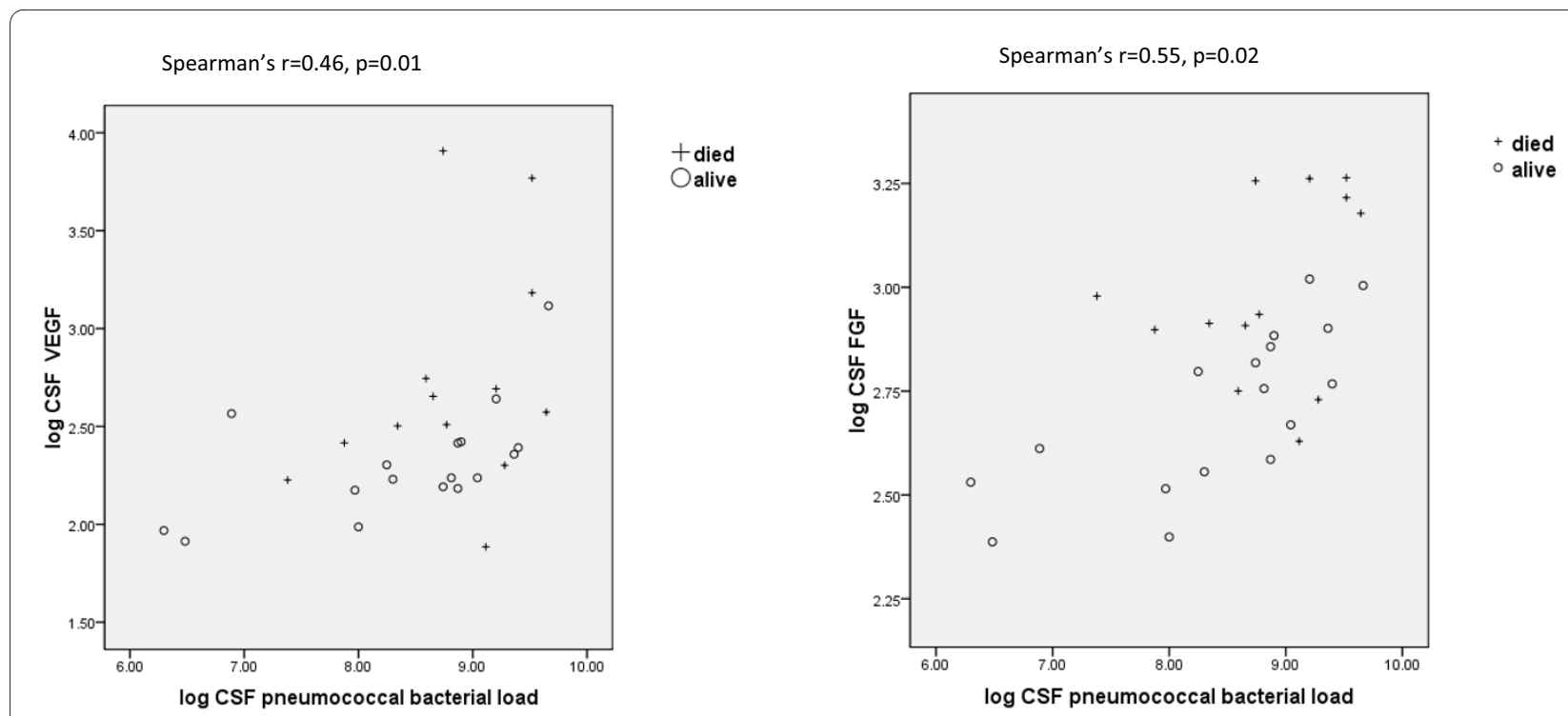

Figure 1 Scatterplot showing CSF VEGF and FGF against CSF pneumococcal bacterial load in children with pneumococcal meningitis.

induced endothelial dysfunction. Consistent with previous work, growth-factor concentrations were significantly higher in cases compared with controls. In contrast to previous studies, which demonstrated highest levels of growth factors in patients with septic shock $[24,25,27,29]$, we showed that levels were lower in those with the most severe disease, defined as having a fatal outcome. Very few of our patients demonstrated septic shock or required aggressive fluid resuscitation. Our data are consistent with those of Brueckmann et al. [26], who demonstrated that adults with PDGF levels $<200 \mathrm{pg} / \mathrm{ml}$ were 7 times more likely to die than were those with higher levels.

Karlsson et al. [28] demonstrated that VEGF concentrations in adult patients with sepsis were lower in nonsurvivors than in survivors, but did not adequately predict mortality. The differences in growth factors between gram-positive and gram-negative infections are difficult to explain. Our study was not designed to explain this differential response. We speculate that differences in the way bacterial cell components stimulate the inflammatory cascade might be responsible. We identified high plasma Ang-1 concentrations and male gender as being

Table 4: Correlation between plasma angiogenic factors and pro- and antiinflammatory cytokines

\begin{tabular}{|c|c|c|c|c|}
\hline & $\begin{array}{c}\text { Plasma IL-1Ra } \\
(\mathrm{pg} / \mathrm{ml})\end{array}$ & $\begin{array}{c}\text { Plasma IL-6 } \\
\text { (pg/ml) }\end{array}$ & $\begin{array}{c}\text { Plasma IL-8 } \\
\text { (pg/ml) }\end{array}$ & $\begin{array}{c}\text { Plasma IL-10 } \\
\text { (pg/ml) }\end{array}$ \\
\hline Plasma VEGF (pg/ml) & NS & NS & $\begin{array}{c}0.22 \\
P<0.0005\end{array}$ & $\begin{array}{c}0.37 \\
P<0.0005\end{array}$ \\
\hline $\begin{array}{l}\text { Plasma PDGF } \\
(\mathrm{pg} / \mathrm{ml})\end{array}$ & $\begin{array}{c}-0.16 \\
P=0.06\end{array}$ & NS & NS & NS \\
\hline $\begin{array}{l}\text { Plasma FGF } \\
(\mathrm{pg} / \mathrm{ml})\end{array}$ & NS & NS & $\begin{array}{c}0.13 \\
P=0.03\end{array}$ & $\begin{array}{c}0.38 \\
P<0.0005\end{array}$ \\
\hline $\begin{array}{l}\text { Plasma Ang-1 } \\
(\mathrm{pg} / \mathrm{ml})\end{array}$ & $\begin{array}{c}-0.37 \\
P<0.0005\end{array}$ & $\begin{array}{c}-0.26 \\
P<0.0005\end{array}$ & NS & NS \\
\hline $\begin{array}{l}\text { Plasma Ang-2 } \\
\text { (pg/ml) }\end{array}$ & $\begin{array}{c}0.53 \\
P<0.0005\end{array}$ & $\begin{array}{c}0.44 \\
P<0.0005\end{array}$ & $\begin{array}{c}0.50 \\
P<0.0005\end{array}$ & $\begin{array}{c}0.34 \\
P<0.0005\end{array}$ \\
\hline
\end{tabular}

NS, not significant. 
Table 5: Multivariate logistic regression model to predict mortality and SBI

\begin{tabular}{|c|c|c|c|c|}
\hline Predictor & $\begin{array}{c}\text { Adjusted OR for } \\
\text { death } \\
(95 \% \mathrm{Cl})\end{array}$ & $P$ & $\begin{array}{c}\text { Adjusted OR for SBI } \\
(95 \% \mathrm{Cl})\end{array}$ & $P$ \\
\hline Female sex & $3.95(1.33-11.76)$ & 0.01 & $1.59(0.47-5.42)$ & 0.46 \\
\hline Meningitis & $9.9 \times 10^{12}$ & 1.0 & $5.91(1.47-23.77)$ & 0.01 \\
\hline HIV uninfected & $0.60(0.18-1.97)$ & 0.4 & $1.18(0.34-4.13)$ & 0.8 \\
\hline Admission lactate & $1.33(0.52-3.37)$ & 0.6 & $3.20(1.20-8.57)$ & 0.02 \\
\hline Plasma FGF (pg/ml) & $1.35(0.52-3.54)$ & 0.5 & $0.94(0.31-2.91)$ & 0.92 \\
\hline Plasma VEGF (pg/ml) & $1.21(0.43-3.42)$ & 0.7 & $5.63(1.32-24.11)$ & 0.02 \\
\hline Plasma PDGF (pg/ml) & $3.17(0.90-11.12)$ & 0.07 & $1.07(0.35-3.28)$ & 0.91 \\
\hline Plasma Ang-1 (pg/ml) & $0.23(0.08-0.69)$ & 0.009 & $0.19(0.58-0.62)$ & 0.006 \\
\hline Plasma Ang-2 (pg/ml) & $0.90(0.45-1.83)$ & 0.6 & $5.40(1.79-16.29)$ & 0.003 \\
\hline
\end{tabular}

independently associated with survival. Our study also supports the concept of intracerebral production of growth factors in bacterial meningitis.

The major limitation of our study was that we studied growth-factor and angiopoietin concentrations only at admission and did not follow their course over time. Admission values are potentially more useful as prognostic markers, if they can be made available to the clinician at the time the patient is first seen, as they could help to identify a group of patients requiring aggressive treatment or characterize those eligible for entry to a randomized clinical trial of adjunctive therapies.

Interventions that target the inhibition of inflammatory mediators and coagulation pathways have been unsuccessful. Recently, microcirculatory dysfunction has been shown to be a critical element of the pathogenesis of severe sepsis [36]. The investigation of host mediators that directly influence endothelial function might therefore be a valuable approach to improve our understanding of the pathophysiology of sepsis.

A recent study demonstrated that activated protein $C$ (APC) uses the angiopoietin/Tie-2 axis to promote endothelial barrier function [37]. Large clinical trials with APC showed a beneficial effect in adult patients with severe sepsis [38], but in children, this effect was not seen [39]. Assessment of the angiopoietin/Tie-2 system might help to identify those children who might benefit from APC therapy or other new adjunctive therapies.
Our study contributes to the understanding of factors controlling endothelial integrity, and our results are consistent with those of previous studies [19,22,26,28]. Although the number of controls in our study was small, the inclusion of a comparator group allows the assessment of possible effects of other asymptomatic coinfections, such as helminths and malaria parasitemia. Three studies in children have reported increased Ang-2 concentrations in severe malaria $[40,41]$ and cerebral malaria $[41,42]$. A recent study from Thailand [41] reported that Ang-1 and Ang-2 discriminated severe from uncomplicated malaria, and Ang-1 distinguished children with severe malaria from those with cerebral malaria. The authors propose that Ang-1 and Ang-2 are attractive candidates for a point-of-care test to identify individuals with a risk of progression to severe disease, as they can be incorporated into rapid lateral-flow immunochromatographic tests such as those used in malaria diagnosis.

As our patient population differs significantly from those of most of the readers of this journal, inferences regarding other study populations may be difficult to make. Nonetheless, we believe that the high mortality in our patients represents the most severe end of the spectrum (that is, MODS without intensive care support), which ultimately results from severe endothelial dysfunction. Although our study does not provide any description of multiorgan dysfunction, data from studies in similar settings suggest that in severely ill children with- 
out malaria, Blantyre Coma Score $[43,44]$ and lactate [44] accurately predict mortality.

The mobilization of endothelial progenitor cells (EPCs) from bone marrow to sites of endothelial injury is induced by angiogenesis. A recent study demonstrated that the number and function of EPCs decreased in the progression of sepsis and may be one of the main pathogenic factors in multiple organ dysfunction syndromes [5]. EPCs are increased in the blood of patients with sepsis, in parallel with VEGF levels [45]. Our data support the concept that the angiogenic factors reported here are important in the pathophysiology of severe bacterial infection.

Studies investigating host responses to infection have shown that most mediators are increased and are positively associated with disease severity. We previously showed that the concentration of the chemokine, Regulated on Activation Normal $\mathrm{T}$ Cells Expressed and Secreted (RANTES) is inversely associated with disease severity in children, both in meningococcal disease [46] and in pneumococcal disease [35]. Others confirmed this finding in meningococcal disease [47]. This study now adds another group of cytokines and angiopoietins that are inversely associated with disease severity.

VEGF has been shown to be elevated in the CSF of children and adults with bacterial meningitis [48] and in adults with cryptococcal meningitis [49]. Both studies suggest that the VEGF is produced intrathecally and may contribute to the blood-brain barrier disruption. Our data would also be consistent with intrathecal production of growth factors. We demonstrated higher CSF than plasma concentrations in paired samples, and higher concentrations of VEGF and FGF in the CSF of children who died. We previously reported data that suggest a compartmentalized host response in pneumococcal meningitis [33]. In contrast to the study by van der Flier [48], we found no association between the CSF growth factors and the CSF white cell count.

Neutrophils have been shown to secrete VEGF in response to pneumococcal stimulation, and we suggest that VEGF may play a role as a mediator of vascular permeability [50]. VEGF and PDGF are working in a complex relation with Ang-1 and Ang-2 to promote endothelial cell survival and to prevent apoptosis [17]. Our data showing a favorable outcome in children with higher plasma levels of FGF, VEGF, PDGF, and Ang-1 would be consistent with this theory. Ang- 2 appears to be acting as an antagonist to the other angiogenic factors and correlates positively with disease severity. The dysregulation of Ang-1 and Ang-2 in severe sepsis may contribute to the endothelial dysfunction and increased vascular permeability that lead to multiorgan failure and mortality.

\section{Conclusions}

We have shown that low plasma VEGF, PDGF, FGF, and Ang-1 concentrations are associated with an unfavorable outcome in children with severe bacterial infection, the association being independent of confounding factors in the case of Ang-1. High Ang-2 concentrations are associated with mortality. In bacterial meningitis, our data support the concept of intracerebral production of growth factors, with increased CSF concentrations in nonsurvivors. VEGF, PDGF, FGF, Ang-1, and Ang-2 may be key players in the endothelial dysregulation seen in severe bacterial infection, or they may simply reflect an attempt by the host to repair endothelial damage. The measurement of these five factors might be useful (a) as prognostic markers of outcome, and (b) in identifying children who might benefit from adjunctive new therapies. Further studies are needed to identify the exact mechanism by which the angiopoietins might affect endothelial function in severe bacterial infection.

\section{Key messages}

- Mean VEGF, PDGF, and FGF concentrations are higher in survivors than in nonsurvivors.

- Mean Ang-1 is significantly increased, and Ang-2 significantly decreased, in survivors compared with nonsurvivors.

- Low Ang-1 is independently associated with mortality.

- In bacterial meningitis, mean CSF VEGF, PDGF, and FGF concentrations were higher than paired plasma concentrations, and mean CSF VEGF and FGF concentrations were higher in nonsurvivors than in survivors.

- Ang-1 could be a useful prognostic marker.

\section{Abbreviations}

Ang-1: angiopoietin-1; Ang-2: angiopoietin-2; FGF: fibroblast growth factor; IPD: invasive pneumococcal disease; NBI: no detectable bacterial infection; PDGF: platelet-derived growth factor; SBI: serious bacterial infection; VEGF: vascular endothelial growth factor.

\section{Competing interests}

The authors declare that they have no competing interests.

\section{Authors' contributions}

EDC designed the study, recruited patients, performed data analysis, and drafted the manuscript. CAH, MEM, and EMM were involved in study design and drafting the manuscript. LAM recruited patients and helped draft the manuscript. IPD Study Group recruited patients. DLB, GJ, PB, SN, and HP performed laboratory analysis and helped draft the manuscript. SW provided statistical advice and helped with data analysis. RSH helped draft the manuscript.

\section{Acknowledgements}

The IPD (Invasive Pneumococcal Disease) Study Group (Nurses: C Antonio, M Chinamale, L Jere, D Mnapo, V Munthali, F Nyalo, J Simwinga; Clinical Officer: M Kaole; Field Workers: A Manyika, and K Phiri). We thank the children included in this study and their parents and guardians for giving consent for them to participate in the study. We also extend thanks to the nursing and medical staff at the Malawi-Liverpool-Wellcome Trust Clinical Research Programme (MLW), Research Ward, for their contribution to this study. 
EDC was supported by a Wellcome Trust Career Development Grant (grant no. 068026). The Malawi-Liverpool-Wellcome Trust Clinical Research Programme is supported by the Wellcome Trust.

CAH died suddenly in September 2007, but in view of his significant contribution to the study, it was agreed that he should be included as a co-author. Presented in part as an oral presentation, 13th Spring Meeting of the Royal College of Paediatrics and Child Health, April 2009, UK. Arch Dis Child 2009; 94(suppl 1): A20

\section{Author Details}

${ }^{1}$ Malawi-Liverpool-Wellcome Trust Clinical Research Programme, College of Medicine, University of Malawi, Blantyre, Malawi, ${ }^{2}$ Department of Paediatrics, College of Medicine, University of Malawi, Blantyre, Malawi, ${ }^{3}$ Health Protection Agency, Manchester Medical Microbiology Partnership, Oxford Road, Manchester, M13 9WZ, UK, 4Division of Child Health, The University of Liverpool, Institute of Child Health, Alder Hey Children's NHS Foundation Trust, Eaton Road, Liverpool, L12 2AP, UK and 5Division of Medical Microbiology, The University of Liverpool, Duncan Building, Daulby Street, Liverpool, L69 3GA, UK

Received: 2 January 2010 Revised: 26 February 2010

Accepted: 21 May 2010 Published: 21 May 2010

\section{References}

1. Watt JP, Wolfson LJ, O'Brien KL, Henkle E, Deloria-Knoll M, McCall N, Lee E, Levine OS, Hajjeh R, Mulholland K, Cherian T: Burden of disease caused by Haemophilus influenzae type $b$ in children younger than 5 years: global estimates. Lancet 2009, 374:903-911.

2. O'Brien KL, Wolfson LJ, Watt JP, Henkle E, Deloria-Knoll M, McCall N, Lee E, Mulholland K, Levine OS, Cherian T: Burden of disease caused by Streptococcus pneumoniae in children younger than 5 years: global estimates. Lancet 2009, 374:893-902.

3. Spronk PE, Zandstra DF, Ince C: Bench-to-bedside review: sepsis is a disease of the microcirculation. Crit Care 2004, 8:462-468.

4. Planat-Benard V, Silvestre JS, Cousin B, Andre M, Nibbelink M, Tamarat R, Clergue M, Manneville C, Saillan-Barreau C, Duriez M, Tedgui A, Levy B, Penicaud L, Casteilla L: Plasticity of human adipose lineage cells toward endothelial cells: physiological and therapeutic perspectives. Circulation 2004, 109:656-663.

5. Luo TH, Wang Y, Lu ZM, Zhou H, Xue XC, Bi JW, Ma LY, Fang GE: The change and effect of endothelial progenitor cells in pig with multiple organ dysfunction syndromes. Crit Care 2009, 13:R118.

6. Kim I, Moon SO, Kim SH, Kim HJ, Koh YS, Koh GY: Vascular endothelial growth factor expression of intercellular adhesion molecule 1 (ICAM1), vascular cell adhesion molecule 1 (VCAM-1), and E-selectin through nuclear factor-kappa B activation in endothelial cells. J Biol Chem 2001, 276:7614-7620.

7. Lucerna M, Mechtcheriakova D, Kadl A, Schabbauer G, Schafer R, Gruber F, Koshelnick Y, Muller HD, Issbrucker K, Clauss M, Binder BR, Hofer E: NAB2, a corepressor of EGR-1, inhibits vascular endothelial growth factormediated gene induction and angiogenic responses of endothelial cells. J Bio/ Chem 2003, 278:11433-11440.

8. Battegay EJ, Rupp J, Iruela-Arispe L, Sage EH, Pech M: PDGF-BB modulates endothelial proliferation and angiogenesis in vitro via PDGF betareceptors. J Cell Biol 1994, 125:917-928.

9. Thommen R, Humar R, Misevic G, Pepper MS, Hahn AW, John M, Battegay EJ: PDGF-BB increases endothelial migration on cord movements during angiogenesis in vitro. J Cell Biochem 1997, 64:403-413.

10. Yaguchi A, Lobo FL, Vincent JL, Pradier O: Platelet function in sepsis. J Thromb Haemost 2004, 2:2096-2102.

11. Karsan A, Yee E, Poirier GG, Zhou P, Craig R, Harlan JM: Fibroblast growth factor-2 inhibits endothelial cell apoptosis by $\mathrm{Bcl}$-2-dependent and independent mechanisms. Am J Pathol 1997, 151:1775-1784.

12. Maier JA, Morelli D, Menard S, Colnaghi MI, Balsari A: Tumor-necrosisfactor-induced fibroblast growth factor- 1 acts as a survival factor in a transformed endothelial cell line. Am J Pathol 1996, 149:945-952.

13. Huang CC, Liu CC, Wang ST, Chang YC, Yang HB, Yeh TF: Basic fibroblast growth factor in experimental and clinical bacterial meningitis. Pediatr Res 1999, 45:120-127.

14. Scharpfenecker M, Fiedler U, Reiss Y, Augustin HG: The Tie-2 ligand angiopoietin-2 destabilizes quiescent endothelium through an internal autocrine loop mechanism. J Cell Sci 2005, 118:771-780.
15. Kim I, Kim HG, So JN, Kim JH, Kwak HJ, Koh GY: Angiopoietin-1 regulates endothelial cell survival through the phosphatidylinositol 3'-kinase/ Akt signal transduction pathway. Circ Res 2000, 86:24-29.

16. Papapetropoulos A, Fulton D, Mahboubi K, Kalb RG, O'Connor DS, Li F, Altieri DC, Sessa WC: Angiopoietin-1 inhibits endothelial cell apoptosis via the Akt/survivin pathway. J Bio/ Chem 2000, 275:9102-9105.

17. Lobov IB, Brooks PC, Lang RA: Angiopoietin-2 displays VEGF-dependent modulation of capillary structure and endothelial cell survival in vivo. Proc Natl Acad Sci USA 2002, 99:11205-11210.

18. Kumpers P, Lukasz A, David S, Horn R, Hafer C, Faulhaber-Walter R, Fliser D, Haller $\mathrm{H}$, Kielstein JT: Excess circulating angiopoietin-2 is a strong predictor of mortality in critically ill medical patients. Crit Care 2008, 12:R147.

19. Giuliano JS Jr, Lahni PM, Harmon K, Wong HR, Doughty LA, Carcillo JA, Zingarelli B, Sukhatme VP, Parikh SM, Wheeler DS: Admission angiopoietin levels in children with septic shock. Shock 2007 28:650-654

20. Phelps ED, Updike DL, Bullen EC, Grammas P, Howard EW: Transcriptional and posttranscriptional regulation of angiopoietin-2 expression mediated by IGF and PDGF in vascular smooth muscle cells. Am Physiol Cell Physiol 2006, 290:C352-361.

21. Orfanos SE, Kotanidou A, Glynos C, Athanasiou C, Tsigkos S, Dimopoulou I, Sotiropoulou C, Zakynthinos S, Armaganidis A, Papapetropoulos A, Roussos C: Angiopoietin-2 is increased in severe sepsis: correlation with inflammatory mediators. Crit Care Med 2007, 35:199-206.

22. Kumpers P, van Meurs M, David S, Molema G, Bijzet J, Lukasz A, Biertz F, Haller H, Zijlstra JG: Time course of angiopoietin-2 release during experimental human endotoxemia and sepsis. Crit Care 2009, 13:R64.

23. Siner JM, Bhandari V, Engle KM, Elias JA, Siegel MD: Elevated serum angiopoietin 2 levels are associated with increased mortality in sepsis. Shock 2009, 31:348-353.

24. van der Flier M, van Leeuwen HJ, van Kessel KP, Kimpen JL, Hoepelman Al, Geelen SP: Plasma vascular endothelial growth factor in severe sepsis. Shock 2005, 23:35-38.

25. Yano K, Liaw PC, Mullington JM, Shih SC, Okada H, Bodyak N, Kang PM, Toltl L, Belikoff B, Buras J, Simms BT, Mizgerd JP, Carmeliet P, Karumanchi SA, Aird WC: Vascular endothelial growth factor is an important determinant of sepsis morbidity and mortality. J Exp Med 2006 203:1447-1458

26. Brueckmann M, Hoffmann U, Engelhardt C, Lang S, Fukudome K, Haase KK, Liebe V, Kaden JJ, Putensen C, Borggrefe M, Huhle G: Prognostic value of platelet-derived growth factor in patients with severe sepsis. Growth Factors 2007, 25:15-24

27. Shapiro NI, Yano K, Okada H, Fischer C, Howell M, Spokes KC, Ngo L, Angus DC, Aird WC: A prospective, observational study of soluble FLT-1 and vascular endothelial growth factor in sepsis. Shock 2008, 29:452-457.

28. Karlsson S, Pettila V, Tenhunen J, Lund V, Hovilehto S, Ruokonen E: Vascular endothelial growth factor in severe sepsis and septic shock. Anesth Analg 2008, 106:1820-1826.

29. Pickkers P, Sprong T, Eijk L, Hoeven H, Smits P, Deuren M: Vascular endothelial growth factor is increased during the first 48 hours of human septic shock and correlates with vascular permeability. Shock 2005, 24:508-512.

30. Choi SH, Park EY, Jung HL, Shim JW, Kim DS, Park MS, Shim JY: Serum vascular endothelial growth factor in pediatric patients with community-acquired pneumonia and pleural effusion. J Korean Med Sci 2006, 21:608-613

31. Bermejo-Martin JF, Garcia-Arevalo MC, De Lejarazu RO, Ardura J, Eiros JM, Alonso A, Matias V, Pino M, Bernardo D, Arranz E, Blanco-Quiros A: Predominance of Th2 cytokines, CXC chemokines and innate immunity mediators at the mucosal level during severe respiratory syncytial virus infection in children. Eur Cytokine Netw 2007, 18:162-167.

32. Payton A, Payne D, Mankhambo LA, Banda DL, Hart CA, Ollier WE, Carrol ED: Nitric oxide synthase $2 \mathrm{~A}$ (NOS2A) polymorphisms are not associated with invasive pneumococcal disease. BMC Med Genet 2009, 10:28.

33. Carrol ED, Guiver M, Nkhoma S, Mankhambo LA, Marsh J, Balmer P, Banda DL, Jeffers G, White SA, Molyneux EM, Molyneux ME, Smyth RL, Hart CA: High pneumococcal DNA loads are associated with mortality in Malawian children with invasive pneumococcal disease. Pediatr Infect Dis J 2007, 26:416-422. 
34. Molyneux ME, Taylor TE, Wirima JJ, Borgstein A: Clinical features and prognostic indicators in paediatric cerebral malaria: a study of 131 comatose Malawian children. Q J Med 1989, 71:441-459.

35. Carrol ED, Mankhambo LA, Balmer P, Nkhoma S, Banda DL, Guiver M, Jeffers G, Makwana N, Molyneux EM, Molyneux ME, Smyth RL, Hart CA: Chemokine responses are increased in HIV-infected Malawian children with invasive pneumococcal disease. J Acquir Immune Defic Syndr 2007, 44:443-450.

36. Trzeciak S, Cinel I, Phillip Dellinger R, Shapiro NI, Arnold RC, Parrillo JE, Hollenberg SM: Resuscitating the microcirculation in sepsis: the central role of nitric oxide, emerging concepts for novel therapies, and challenges for clinical trials. Acad Emerg Med 2008, 15:399-413.

37. Minhas N, Xue M, Fukudome K, Jackson CJ: Activated protein C utilizes the angiopoietin/Tie2 axis to promote endothelial barrier function. FASEB J 2010, 24:873-881.

38. Bernard GR, Vincent JL, Laterre PF, LaRosa SP, Dhainaut JF, LopezRodriguez A, Steingrub JS, Garber GE, Helterbrand JD, Ely EW, Fisher CJ Jr: Efficacy and safety of recombinant human activated protein $\mathrm{C}$ for severe sepsis. N Engl J Med 2001, 344:699-709.

39. Nadel S, Goldstein B, Williams MD, Dalton H, Peters M, Macias WL, AbdAllah SA, Levy H, Angle R, Wang D, Sundin DP, Giroir B: Drotrecogin alfa (activated) in children with severe sepsis: a multicentre phase III randomised controlled trial. Lancet 2007, 369:836-843.

40. Yeo TW, Lampah DA, Gitawati R, Tjitra E, Kenangalem E, Piera K, Price RN, Duffull SB, Celermajer DS, Anstey NM: Angiopoietin-2 is associated with decreased endothelial nitric oxide and poor clinical outcome in severe falciparum malaria. Proc Nat/ Acad Sci USA 2008, 105:17097-17102.

41. Conroy AL, Lafferty EI, Lovegrove FE, Krudsood S, Tangpukdee N, Liles WC, Kain KC: Whole blood angiopoietin-1 and -2 levels discriminate cerebral and severe (non-cerebral) malaria from uncomplicated malaria. Malar J 2009, 8:295.

42. Lovegrove FE, Tangpukdee N, Opoka RO, Lafferty El, Rajwans N, Hawkes M, Krudsood S, Looareesuwan S, John CC, Liles WC, Kain KC: Serum angiopoietin-1 and -2 levels discriminate cerebral malaria from uncomplicated malaria and predict clinical outcome in African children. PLOS ONE 2009, 4:e4912.

43. Molyneux E, Walsh A, Phiri A, Molyneux M: Acute bacterial meningitis in children admitted to the Queen Elizabeth Central Hospital, Blantyre, Malawi in 1996-97. Trop Med Int Health 1998, 3:610-618.

44. Planche T, Agbenyega T, Bedu-Addo G, Ansong D, Owusu-Ofori A, Micah F, Anakwa C, Asafo-Agyei E, Hutson A, Stacpoole PW, Krishna S: A prospective comparison of malaria with other severe diseases in African children: prognosis and optimization of management. Clin Infect Dis 2003, 37:890-897.

45. Becchi C, Pillozzi S, Fabbri LP, Al Malyan M, Cacciapuoti C, Della Bella C, Nucera M, Masselli M, Boncinelli S, Arcangeli A, Amedei A: The increase of endothelial progenitor cells in the peripheral blood: a new parameter for detecting onset and severity of sepsis. Int I Immunopathol Pharmacol 2008, 21:697-705.

46. Carrol ED, Thomson AP, Mobbs KJ, Hart CA: The role of RANTES in meningococcal disease. J Infect Dis 2000, 182:363-366.

47. Moller AS, Bjerre A, Brusletto B, Joo GB, Brandtzaeg P, Kierulf P: Chemokine patterns in meningococcal disease. J Infect Dis 2005, 191:768-775

48. van der Flier M, Stockhammer G, Vonk GJ, Nikkels PG, van DiemenSteenvoorde RA, van der Vlist GJ, Rupert SW, Schmutzhard E, Gunsilius E, Gastl G, Hoepelman Al, Kimpen JL, Geelen SP: Vascular endothelial growth factor in bacterial meningitis: detection in cerebrospinal fluid and localization in postmortem brain. J Infect Dis 2001, 183:149-153.

49. Coenjaerts FE, van der Flier M, Mwinzi PN, Brouwer AE, Scharringa J, Chaka WS, Aarts M, Rajanuwong A, van de Vijver DA, Harrison TS, Hoepelman Al: Intrathecal production and secretion of vascular endothelial growth factor during cryptococcal meningitis. J Infect Dis 2004, 190:1310-1317.

50. van Der Flier M, Coenjaerts F, Kimpen JL, Hoepelman AM, Geelen SP: Streptococcus pneumoniae induces secretion of vascular endothelial growth factor by human neutrophils. Infect Immun 2000, 68:4792-4794.

\section{doi: $10.1186 /$ cc9025}

Cite this article as: Mankhambo et al., The role of angiogenic factors in predicting clinical outcome in severe bacterial infection in Malawian children Critical Care 2010, 14:R91

\section{Submit your next manuscript to BioMed Central} and take full advantage of:

- Convenient online submission

- Thorough peer review

- No space constraints or color figure charges

- Immediate publication on acceptance

- Inclusion in PubMed, CAS, Scopus and Google Scholar

- Research which is freely available for redistribution

Submit your manuscript at www.biomedcentral.com/submit
C Biomed Central 